\title{
Islamic Religious Education in State Funded Muslim Schools in Sweden: A Sign of Secularization or Not?
}

\author{
Jenny Berglund
}

\begin{abstract}
In this article the establishment of publicly funded Muslim schools in Sweden is described and analysed. This is done by reference to relevant debates about these schools as well as to the content of the extracurricular subject Islamic Religious Education (IRE), which is what distinguishes a Muslim school from other schools in Sweden. The article also raises the question to what extent the appearance of IRE within publicly funded Muslim schools implies that Islam in the Swedish context is turning into what José Casanova has termed a 'deprivatized public religion'. It claims that Islam to a certain extent tends to be viewed as deprivatized even though it is not articulated in this way in schools. The conclusion drawn in relation to the study presented in this chapter is that Islam is rather following the Swedish secularization pattern and is not viewed as an alternative societal order which instead would indicate a de-privatization.
\end{abstract}

Swedish society in the twenty-first century is ethnically, culturally and religiously diverse, with equally diverse opinion as to how this plurality should be managed. While plurality is not a new phenomenon in Sweden, its character has changed, most notably in relation to minority demands. During the sixties and seventies, as in most European countries, most minorities simply asked 'to be left alone ... [and] ... civilly tolerated' (Modood \& Kastoryano 2006:171). Today this is no longer enough, as they increasingly seek augmented recognition and respect as citizens with equal rights. This shift could be understood as a rejection of the notion that minorities should assimilate to the majority 
culture in the public sphere and only express cultural differences privately, and a corresponding call for the acceptance of cultural and ethnic difference in both the private and the public spheres (Modood \& Kastoryano 2006:171). The tension between assimilation and public acceptance of cultural differences is relevant to our understanding of the establishment of Muslim schools, since one way of understanding these is as examples of political engagement developing out of the demand for recognition and equality (see for example: Bergesen 2003; Berglund \& Larsson 2007; Jackson 2003, 2005; Jensen 2004; Maréchal 2002). In Sweden, these Muslim schools are financed by the state but run privately.

This article is based on a study I conducted for my dissertation: 'Teaching Islam, Islamic Religious Education in Sweden' (Berglund 2010). The study was ethnographic, concentrating on daily life in classrooms and the cultural practices of Islamic Religious Education (IRE), the extracurricular subject, that in terms of schedule, distinguishes Muslim from non-Muslim schools. ${ }^{1}$

In this article I will first describe and analyse the establishment of Muslim schools in Sweden by reference to relevant debates about these schools. I will then present and discuss the content and variations of what the IRE teachers most often call 'Islamic history', which is a part of IRE that could be found in all Muslim schools. ${ }^{2}$

In the concluding part, I will discuss to what extent the appearance of IRE within publicly funded Muslim schools implies that Islam in the Swedish context is turning

\footnotetext{
${ }^{1}$ Since the term 'Islamic education' has been applied to various types of Muslim education, I will use the term Islamic Religious Education (IRE) referring specifically to extra-curricular school subjects that have a confessional character and are found in Muslim schools in Sweden. Thus, IRE refers to all confessional subjects offered in the schools in case, even though the schools refer to them in other terms (e.g., Quran, $\operatorname{din}$ [religion], Islam, religion-Islam).

${ }^{2}$ In most schools IRE also contains classical Quran education, i.e. learning the Quran by heart, but note that this is not the case in all schools. Some sort of singing lesson is also common within IRE, but the kind of singing varies widely, see Berglund 2010.
} 
into what José Casanova has termed a 'deprivatized public religion', i.e. whether Islam in IRE is employed to renegotiate and shift established boundaries between the private and public spheres, or if it is simply accommodated to a Swedish Protestant view of religion as personal faith and morality, and as such a religious signifier of the nation. Studying Muslim schools and IRE could be a fruitful way to learn about Swedish Islam and its relation to secularization (Casanova 1994:6), since schools are powerful means to foster the attitudes of the younger generation, what is taught about Islam in these schools indicates what some Swedish Muslims perceive as vital knowledge for a growing generation in a secular country like Sweden.

The Islamic religious education presented in this article does not represent IRE as taught in all Swedish Muslim schools. Nonetheless, after visiting nine out of the sixteen Swedish Muslim schools that offer IRE and conducting interviews with teachers and headmasters alike, it appears that most of the themes presented here do recur in other classrooms, although perhaps treated differently. ${ }^{3}$ It has been argued that teaching at Muslim schools should not be seen as an example of Swedish Islam, i.e. as a product of Swedish society, but rather as the product of isolated communities segregated from the Swedish society wanting to transmit a conservative interpretation of Islam with little or no connection to Swedish society and values (Carlbom 2003). However, this conclusion is based on the experience from one particular Muslim school which is not among the three main sites of my fieldwork. My counterargument is that ethnographic study of the content of IRE in Muslim schools is a means of better understanding the institutionalization of Islam in Sweden, and as such IRE in any Muslim independent school is necessarily the product of Swedish society, and could thereby potentially include signs that are possible to construe in terms of secularization or not. While it may not be possible to generalize the results of a qualitative study such as this, the knowledge derived about the lived classroom experience of IRE has implications for the

\footnotetext{
${ }^{3}$ It would of course be interesting to determine which elements of IRE content are representative of all Muslim schools in Sweden.
} 
general European discussion on confessional education-increasingly viewed as an important alternative by both state and private school facilities.

\section{Background: RE in Sweden}

For Muslims as a religious minority in Sweden there are many challenges. One such challenge is the question of Islamic education and instruction. How to 'transmit' religious tradition to the coming generation is known as one of the most important questions for survival of a religious minority. ${ }^{4}$ Some Muslim children attend supplementary classes at afternoons and weekends to learn about their religious tradition, others are taught at home. Crucial questions in this discussion are who should have responsibility for this instruction and what interpretation of Islam should be taught. Of importance for our discussion about teaching Islam is the position of religious education (RE) within the public school system.

In every country religious education has been shaped by a specific combination of factors, e.g. the structure of its educational system, the political history etc. The country's religious disposition is also significant since the dominance of a particular religious tradition often shapes the educational system, even where religious freedom is guaranteed. The Swedish school system has a long history of Christian education related to the Lutheran State Church. Although schooling was made compulsory for all children in 1842, Sven Hartman notes that 'Swedes [had been] a reading people' long before then - a result of the Ecclesiastical Act of 1686 which charged parents and masters with the domestic responsibility of teaching their children and servants to read. At that time the most important school subject was religious instruction and it remained so until a major curriculum adjustment was undertaken in 1919, the starting point of the secularization of Swedish schools. From then on religious instruction was reduced by half, other subjects were introduced, and '[f]ostering for national citizenship instead of the Lutheran faith became the task of the school system' (Hartman 2007: 260). In 1962 another school reform required the subject of Christianity to maintain a 'neutral' profile

\footnotetext{
${ }^{4}$ See Berglund (2011) for a discussion about 'transmitting' religious traditions.
} 
with respect to questions of faith; and in 1969, the subject's name was changed from Christianity to Religious Education (religionskunskap), indicating the transition from confessional to non-confessional religious education that prioritized teaching about religion-including different religions - from a Study of Religions perspective. From then on Religious Education also became more pupil-centred, focusing increasingly on 'life questions'. The Swedish national curriculum states:

Education in the Swedish school system shall be non-denominational [nonconfessional]. The task of the school is to encourage all pupils to discover their own uniqueness as individuals and thereby actively participate in social life by giving of their best in responsible freedom. (Curriculum for the Compulsory School System, the Pre-school Class and the Leisure-time Centre 1994).

The use of the term non-denominational (icke-konfessionell) in the above quotation implies that in the Swedish school system religious education is to be presented so that no particular worldview is prioritized and pupils from all cultural, ethnic and religious backgrounds feel comfortable to attend. This neutrality, however, does not extend to what is described as society's 'foundational values', the mediation of which the national curriculum considers a primary educational task. The curriculum states:

The school has the important task of imparting, instilling and forming in pupils those foundational values on which our society is based. The inviolability of human life, individual freedom and integrity, the equal value of all people, equality between women and men and solidarity with the weak and vulnerable are all values that the school should represent and impart. In accordance with the ethics borne by Christian tradition and Western humanism, this is achieved by fostering in the individual a sense of justice, generosity of spirit, tolerance and responsibility.

In accordance with Sweden's Education Act, the general goals outlined in the above quotation are meant to be achieved in both non-denominational and denominational 
settings, and thus the 'objectivity' of education is not to be intruded upon by indoctrination or tendentious modes of discourse, regardless of the school's profile. Schools with confessional profiles can set aside a few hours per week for religious subjects as an extracurricular activity. In the case of Muslim schools, this amounts to one to three hours per week of Islamic religious education. And since there is no national syllabus for such subjects, local syllabi must be written instead. These must also adhere to the national 'foundational values'.

\section{The Establishment of Muslim Schools}

In 1992 Sweden changed its educational policies to allow for a range of private actors to obtain state funding for so-called 'independent schools'.5 In 1993 Sweden's first Muslim school opened in the city of Malmö; to date, that number has increased to fifteen. Of these, nine have been classified as 'Islamic' by the Swedish National Agency for Education (see table below) and six have been classified as 'Swedish-Arabic' or the like. Because some of the schools characterized as 'Swedish-Arabic' provide some sort of IRE-e.g., lessons in the Quran — this study considers them to be 'Muslim' as well. Each such Muslim school currently educates between 20 and 250 pupils.

Schools classified as 'independent' are generally divided into three distinct profile categories: 'Denominational'; 'Waldorf'; and 'General'. Among the denominational we find the Christian, Jewish and Muslim schools. According to the Education Act, independent schools must open their doors to everyone, regardless of faith, and must be approved by the National Agency for Education. The nature of one denominational school may be extremely different from another. A distinction is often drawn between 'strong' and 'weak' profiles, depending on the impact that a specific religion has on the profile of the school. Even though a small number of Christian schools and one Jewish school existed in Sweden before the 1990s, the policy change led to a vast increase of denominational schools:

\footnotetext{
5 The word independent here refers to the fact that the schools are run independently, i.e. they are run privately, not by the municipality, even though they receive public funding.
} 


\begin{tabular}{|l|l|l|l|}
\hline & Christian & Muslim & Jewish \\
\hline Compulsory schools & 54 & 9 & 3 \\
\hline Upper secondary schools & 6 & 0 & 0 \\
\hline
\end{tabular}

Table 1: Denominational schools in Sweden (Skolverket 2006)

Although the table only lists schools designated as 'denominational' by Sweden's National Agency for Education, it nonetheless indicates that there are much fewer Muslim schools than Christian. It also shows that Muslim schools remain within the compulsory segment of the Swedish school system, no Muslim upper secondary schools having yet been established (nearly all pupils continue to upper secondary school even though it is not compulsory).

The education offered by all independent schools must have the same basic aims as the education offered by municipal schools, while they can have a religious 'profile' ${ }^{6}$ This profile often consists of a specific school ethos and additional curricular subjects that are incorporated into the weekly schedule. The aims of the school subjects that are stipulated in the national syllabi also have to be pursued in independent schools, this means that the aims of RE, as a non-confessional school subject, for example, to provide knowledge about different religions, also have to be reached in all schools. At most Muslim schools this is done by separating RE from IRE, where RE is taught together with history and social science by one teacher and IRE by another (Muslim) teacher.

Considering the reasons for establishing Muslim schools in Sweden, a study conducted in 1997 by the Swedish National Agency for Education concluded that certain Muslim parents send their children to Muslim schools because of negatively biased and inaccurate views of Islam in municipal schools and schoolbooks; disregard for common

\footnotetext{
${ }^{6}$ Municipal schools might also have a special profile, for example, football, arts or a specific pedagogy. So far though, there are no municipal schools that have chosen (or even tried to) establish a denominational profile.
} 
Islamic rules regarding diet, dress, prayer, chastity, fasting, and so forth; poor religious education by the standards of Islam; insufficient discipline; fear of exposure to narcotics and alcohol; and too great a diversity of immigrant groups in the neighbouring municipal schools. Another important reason concerns the difficulties encountered by these Muslim parents in their interactions with municipal school officials and staffsinteractions that had left them feeling humiliated and alienated. Reportedly, it was such incidents that convinced them that it was impossible to execute their parental responsibilities effectively within the municipal school framework; thus they opted to send their children to a Muslim school instead. A more recent study indicates the same thing: parents choose to send their children to Muslim schools more for purposes of security and well-being than for the purpose of religion although the criticism against the perceived 'neutral' position mentioned above also exists (Bunar \& Kallstenius 2006). Thus their choice might be seen as one way of avoiding discrimination and obtaining acceptance of difference-i.e., as primarily involving concerns over power of influence and democratic rights. It is impossible to exclude such considerations from any comprehensive discussion regarding Muslim schools in Sweden. Ajagan-Lester (2001) even claims that the establishment of Muslim schools in Sweden might be seen as a reaction against municipal schools as they have only heteronomy and submission to offer to minority pupils. Whether or not one accepts the validity of this reasoning, it is also important to many Muslim parents to find an educational environment where their children can be educated not only about Islam via RE textbooks based on a secularized religious studies approach, but also into Islam via confessional lessons in which Islam is the norm and the child learns about the 'good life' from the Islamic point of view. Choosing education into Islam could thus also be understood as opposition to education into secularism, which is the 'neutrality' that municipal schools are considered to uphold. A surprising circumstance for this discussion is that there are to date no available statistics comparing the performances of Muslim pupils in Muslim and municipal schools, which would have been interesting for the present discussion. 
Although, as indicated above, the decision to send one's child to a Muslim school is not always based on the fact that it offers IRE, this extracurricular subject in the school syllabus is nonetheless what formally distinguishes Muslim 'free schools'. As will be demonstrated below, its content shows how IRE is formed within the framework and under the jurisdiction of the Swedish school system.

\section{Method}

The aim of my fieldwork has been to gather an extensive and diverse collection of information. The first step was to gain access to a number of Muslim schools, which turned out to be far more difficult than I had imagined. The causes of initial resistance appeared to centre upon the ongoing debate over Sweden's denominational schools and the increasing threat felt by Muslims due to the rise of Islamophobia. With particular reference to Muslim schools, two covertly filmed television programmes had raised fears that ill-intentioned guests might bring hidden cameras or other recording devices into the school to further their own agendas (These programmes, titled I skolans våld (In the School's Clutches) were broadcast on 8 May 2003 and 12 May 2004. The programmes were part of the series Dokument inifrån, which examines aspects of Swedish society considered of general interest. The reporter with the hidden camera found that several headmasters were so eager to get pupils enrolled in their school (and thereby get the financial support from the state that is tied to each pupil) that they were prepared to accept claims from parents that were not in line with the national curriculum.

Out of the sixteen schools that I initially contacted I was ultimately able to visit nine. From those nine I eventually selected three. These particular schools were chosen for the study because their IRE lessons were given in Swedish.

Observation mainly took place in IRE classrooms but also in corridors, canteens and in the schoolyard. In the IRE classrooms I sat on a chair located either at the back of the room or next to one of the pupils; from this vantage point I observed what was going on, continuously taking notes. While priority was given to the experiences and 
viewpoints of the informants in order to comprehend their culture and religion, it should be acknowledged that their viewpoints are ultimately mediated by me as researcher. The primary focus was on the statements and conduct of the teachers, although I also recorded the questions, answers and reactions of the pupils, as reference points for both the teachers and myself. Interviews have been a necessary complement to observation, since it has been through interviews that informants were able to explain the organization of their teaching and indicate the system of meaning that informed their lessons. The aim of these interviews has been to create a narrative that provides the reader with new insight and simultaneously does justice to the personal expression of each informant's point of view. Questions concerning the teaching behaviour that I had just observed directed the interview process; in this way, observation and interview worked together. My first intention was to tape-record the interviews. From the start, however, it was obvious that the tape recorder would be a cause of distraction and anxiety for teachers and pupils alike. ${ }^{7}$ What has helped in this regard is my experience of teaching in a Muslim school. ${ }^{8}$

\footnotetext{
${ }^{7}$ One reason for this type of negative reaction is the belief of many of the teachers that the above mentioned television programmes manipulated audio-video footage to misrepresent Muslim school life. Understanding this point of view, I decided to take notes while interviewing and observing, turning these into field descriptions shortly thereafter and then allowing my informants to review these writings to insure that they contained no misunderstandings. This approach turned out to be extremely fruitful since the field notes often became the basis of conversations about what had transpired during the lessons. Within the discipline of ethnography it is often acknowledged that the presence of tape and/or video recorders might discourage informants; see Hammersley and Atkinson (1995:185) and Glaser (1998, Chapter 7) which proffers a number of arguments against the recording of interviews for grounded theory research, the primary one being that since descriptive completeness is not a goal, it is not necessary to record and transcribe interviews.

${ }^{8}$ Between 1999 and 2003 I taught mathematics, Swedish, English, physical education and the natural and social sciences in a Muslim school. Helene Johnson and Mike Castelli have shown that many researchers that have studied Muslim schools in England have lacked knowledge and previous social interaction with this kind of environment. For them 'it is clear that orientalism must be faced head on and that there are important issues here for researchers about the achieving of an objectively informed position'-
} 


\section{Islamic History in IRE}

All of the schools that were objects of this study offered IRE as an extracurricular subject one to three hours per week on top of the school subjects, including RE, that are required by the national curriculum. These hours of education were occupied by the teaching of the Quran, Islamic history and Islam-related songs. ${ }^{9}$ I will provide some descriptions of how Islamic history is used in IRE, since the ways in which history is used in IRE indicate differences in how Islam is interpreted in relation to Swedish majority society.

At all schools, IRE features the teaching of Islamic history through religious narratives from hadith, sira and qissa. The messages contained within these narratives could be understood in terms of providing Muslim role models; explaining the Quran and thereby establishing the 'right faith'; and, not least, entertaining the children.

Most narratives selected for use in the classrooms indicate what each teacher considers correct Muslim behaviour, as apparent through the examples of prophets and other important figures from Islamic history where the moral message stands out. For example, Fatme's approach to teaching is grounded in her view that it is important to avoid creating 'us-them' dichotomies between 'Muslims' and 'Swedes' (or non-Muslims). To avoid such dichotomies, she selects historical narratives that can be related to the contemporary circumstances of her pupils and attempts to show that both Islamic culture and Swedish society regard similar types of behaviour as 'good' (Interview with Fatme 20/12/06). Fatme repeatedly emphasizes that 'Islam is a private matter', and often contrasts her view with the view she claims is prevailing in the Swedish media; that Islam mixes religion and politics (Interview with Fatme 20/12/06). Her way of talking about Islam as 'private' could rather be understood as meaning personal and

\footnotetext{
something that has become even more apparent in the aftermath of 9/11; Johnsson and Castelli 2002:389.

${ }^{9}$ The remainder of each school's general schedule consisted of the standard subjects prescribed by the Swedish national curriculum.
} 
resembles the way many secularized Protestants in Sweden would talk about religion. She relates this notion of Islam as 'private' (personal) to her choice of narratives, specifically to narratives that contain moral messages that she believes are 'good for their identity'. She says that 'in Sweden the choice of behaviour is more up to the individual', indicating that in other societies this would be more of a collective responsibility. Her choice of narratives can thus be understood in terms of her selfdescribed educational aims: to help pupils to become secure as Muslims and 'obtain a good foundation for their identity' as Swedish Muslims (Fatme 19/10/05). The use of narratives to exemplify ideal Muslim conduct points not only to the significance of the past, but also to its relevance for both the present and the future. This could be seen in the selection of narratives that are considered relevant to the situation of Muslim pupils in modern-day Swedish society-e.g., narratives that concern the importance of generosity and good behaviour towards neighbours. This particular use of narratives can be characterized as a way of connecting the 'macro' world of Islamic history to the 'micro' world of the pupils.

In this connection it is interesting to see that all female teachers (most IRE teachers in Sweden's Muslim schools are female) acknowledge the scarcity of female role models in the available teaching materials and they have therefore developed specific strategies for dealing with this deficiency; one of these was to identify and introduce narratives about important women in Islamic history. Many of the Islamic narratives that present historical figures as role models are gendered, in the sense that nearly all historical religious stories, regardless of the tradition, involve men rather than women. All three teachers expressed concern over the paucity of narratives with women as role models and described their attempts to compensate; all of them confirmed the necessity of acknowledging and highlighting the role of women in Islamic history:

Noor: It is important to show strong women; some people forget that (Noor 17/03/05). 
Fatme: It is important for the girls to hear about the women that are part of Islamic history; the narratives show the pupils that women have a good position within Islam (Fatme 20/09/05).

Sana: I tell about women in Islam so that the pupils can have female role models, and also to counteract the image they get from the media, which depicts Islam as oppressing women. This is in line with the national curriculum. There are parents that do not know so much about Islam; thus they allow the boys to dominate. (Sana 17/10/05).

Each teacher's choice of narratives determines the manner in which gender is represented to her pupils. In other words, both the choice of a given narrative and the manner in which it is told are related to the way that gender is presented and negotiated in the classroom. In general, however, and despite the teachers' best intentions, most of the narratives they have at their disposal are male-dominated and tend to uphold traditional gender role models (cf. Raudvere 2002:10).

One example of a narrative involving an important woman in Islamic history comes from Noor, who recounts to her fourth-grade class the story of the karamat (marvels) made by Nafiza. Noor tells her class that the narrative comes from the book, Attariq almahbub lidukhul al-qulub (The path of the beloved [in order] to enter [the] hearts). It can be seen lying on her desk. She explains that the book is about 'narratives, prophets and strong women':

Nafiza was a waliya - a friend of God [feminine form]. Her neighbour was a Jewish woman whose daughter happened to be handicapped. The woman asked Nafiza if she could help her daughter. Nafiza made $w u d u$ and then rubbed her $w u d u$-water on the girl's body. The girl became free of her handicap, and both she and her mother became Muslims. (Classroom observation 17/03/05).

Noor defines the word karamat as 'fantastic happenings that are not quite on the level of miracles'. She also notes that while 'only prophets can create miracles, both male 
(waliy) and female (waliya) friends of God can create fantastic happenings' (Noor 17/03/05). Noor's belief in the necessity of introducing narratives about women can be understood to mean that since there are many more narratives about men, it is her educational duty to show that there are many significant women in Islamic history. She indicates that by highlighting the religious accomplishments of 'strong' Muslim women she is doing her part to counteract the prevalent image of women as the weaker sex.

Fatme also notes that she uses a special book about women in the Quran to supplement the narratives that are included in her regular teaching materials. ${ }^{10}$ This book contains tales involving important women in Islamic history, indicating to her pupils that 'women have good status within Islam' (Fatme 20/09/05). Another reason for the inclusion of these specialized books is mentioned by Sana at the beginning of this section: to counteract the negative picture of Muslim women that dominates Swedish society. This is in keeping with the opinions of Fatme and Noor as well. ${ }^{11}$

Sana supplements her teaching with the book Tahrir al-mar'a fi 'asr ar-risala (The Liberation of Women in the Time of the Message, i.e. the Prophet's message) by 'Abd al-Halim Abu Shaqqa (1990). ${ }^{12}$ She considers the book important because it describes how Muslim women have often been hindered by sadd al-dharai, a precautionary principle intended to forestall deeds that, if pursued, might lead to conduct that is not permitted (Izzi Dien 2008). She explains that 'some have used this rule to stop women, while others have misunderstood it. The book is important because it proves that arguments in support of this rule have been frequently misinterpreted.' (Sana 24/10/05).

\footnotetext{
${ }^{10}$ I asked Fatme for the title and author of this book, but was told that she keeps it at home and remembers neither its title nor its author. It should be noted, however, that Jesus' mother 'Maryam' is the only woman named in the Quran; see, for example, sura al-Maida (Q 5:110).

${ }^{11}$ To verify the argument that Sweden's impression of Muslim women is predominantly negative, see, for example, Integrationsverket 2006:159-162, which exemplifies Swedish attitudes towards the practice of veiling.

12 Sana's utilization of a book by Abu Shaqqa is in keeping with her reformist stance (discussed above). See, for example, Roald 2001:133-5.
} 
During my fieldwork, Sana often mentioned misunderstanding or misinterpretation as a primary cause of the circumstances of Muslim women. However, she also mentioned that there was 'too much talk about men and women and differences' and considered it more productive to 'talk about "people" and what they should do' (Sana 21/10/05). Like the other teachers, Sana often chooses narratives describing Muslim women as strong, as she considers this to be in keeping with the national curriculum (Sana 17/10/05 and 21/11/05). The portion of the national curriculum she refers to states that the equality of women and men is one of the fundamental values upon which our society rests, and that it is the duty of educational institutions to impart this value and instil it in their pupils (Curriculum for the Compulsory School System, the Pre-school Class and the Leisuretime Centre 2006:3). ${ }^{13}$

Comparing statements made by the teachers with my own observations of their classrooms, it appears that Sana has the most explicit strategy for furthering the status of Muslim women. For example, in response to the paucity of teaching materials that depict female images, she utilizes more than just one supplementary book, ordering additional books from abroad and copying their relevant pages for her own and her pupils' use. One reason for this is that she considers some other pages of the same books to be deficient because they contain few pictures of girls or of boys and girls doing things together (Sana 24/10/05). Since in Swedish society boys and girls participate together in most activities, Sana wants the same principle to be reflected in the images she employs in her classroom. Thus she tends to select books that have been produced in either Jordan or France, since these contain images of Muslims and Christians living together in harmony as well as a good many that depict Muslim girls (Sana 24/10/05). The way the teachers use Islam could be construed not only as a means to argue for the position of women but also as a way (at least on a discursive level) to equate Islam with a public document such as the national curriculum, a strategy that could be understood as a sign of deprivatization (Casanova 1994).

\footnotetext{
${ }^{13}$ Note that the national curriculum in Sweden also states that 'schools are responsible for counteracting traditional gender roles'.
} 
Narratives are also used in IRE to establish the 'right faith' in competition with other interpretations of Islam-i.e., the faith that the teachers regard as authentic Islam. Sana believes it is possible for Islam to guide all aspects of life, which she sees as the 'correct' way to practise Islam. She explains: 'There are many common denominators between the Swedish welfare state and Islam-for example, the call to help the poor' (Sana 12/10/05). The way that she brings this view to bear on her pupils is made clear in the following lesson about sadaqa (voluntary alms) and zakat (religious $\operatorname{tax})$ :

The class talks about the earthquake that just occurred in Pakistan and Sana says: 'Muhammad said that humanity should be like a body: if there is pain in one part, the other parts cannot feel good. [In the same way], if those in one country are having problems, those in other countries must help them. We teachers are going to collect money to send to the earthquake victims, just as we did to the victims of the tsunami. One can send clothes, money, medicine and other things that are needed, but one should also perform dua [the prayer of request]'.

Many pupils join in the discussion, telling about circumstances in which they encountered the poor and their families gave food or money in charity. Sana remarks that it is very good to share with others.

Sana comments upon the stories told by her pupils: 'Think about two different societies: in one, everyone eats and drinks well and has enough clothes and money - and everyone shares with others; in the other, some are very rich and some are very poor. Where would you want to live?' (Classroom observation $12 / 10 / 05)$.

She begins to tell a mathal: 'Once there was an old man that had three boys. He had a big farm that produced a great deal of fruits and vegetables. After picking the fruits and vegetables, he always called upon the poor to give them all that was left. But his children thought it would be better to sell what was left so they could 
become rich. When the father died, the sons planned to pick all the fruits and vegetables before the sun rose and the poor arrived [to receive their share]. They went in the night and tried to find the garden, but could not because everything had been destroyed. Here Allah gives proof that if you do not share with others, everything will be destroyed. Does anyone know these verses?' (Classroom observation 12/10/05).

No one answers and Sana goes on to recite and explain the verses herself [they can be found in Q 68:33-34]: 'As long as they shared with others, Allah gave baraka to their farm; but the sons' did not to want to continue their father's practice and Allah knew this' (Classroom observation 12/10/05).

Because Sana's narrative closely resembles that which is found in the Quran, it provides an example of a tale used to bring meaning to the Quran and shows how teachers use narratives from Islamic history as a means of providing explanations for the Quran. Sana explains her attempt to indicate to her pupils that God is just and that caring for the poor is an important virtue. As the lesson continues, Sana attempts to show her pupils how zakat can work on a greater societal level. She asks:

Has anyone heard of Umar ibn Abd al-Aziz? After the time of the four caliphs, there was some chaos. After the chaos, people became a little weaker. Umar was young and rich. When he received the responsibility of being caliph, he really started to follow the Prophet Muhammad. He ordered everyone to pay zakat and they went out in search of the poor. But there were no poor to be found because everyone was sharing with each other. [Umar] did much for those without any money. He found them jobs and gave them money for their marriages. He also found support persons [resursperson] for all those that were handicapped. (Classroom observation (12/10/05).

Sana attempts to link the remote time of caliph Umar II with contemporary Sweden by highlighting aspects of the narrative which are recognizable to her pupils and mirror 
features of the modern world. For example, the challenge of finding a job is likely something that Sana's pupils are familiar with, since a significant percentage of their parents remain unemployed - at least according to Sana. They are also likely aware of the extensive costs of getting married: the big wedding, the new home and so forth. The notion of a 'support person' is also something that her pupils can comprehend, since some school children with special needs have support persons of their own. ${ }^{14}$ Sana's teaching of this narrative can be viewed as an attempt to link the Islamic pillar zakat with Swedish welfare values. It also illustrates how the school context influences the way she tells the narrative.

During our post-lesson interview, Sana explains that it is important for the children to see the link between Islam and the Swedish welfare state, e.g. by comparing national welfare benefits to Umar b. Abd al-Aziz's support for the poor (Sana 07/12/06). As a teacher of Muslim children, Sana thus appears committed to finding points of similarity, agreement and harmony between Islam and Swedish society, since it would be just as easy to find points of difference, disagreement and discord. Clearly, the eighth-century reign of Umar b. Abd al-Aziz could have supplied numerous negative contrasts, had that been Sana's aim.

Sana's presentation of the narrative of Umar b. Abd al-Aziz gives Islam a social meaning, since his rule is proffered as a model of good Islamic governance. Speaking of Islam in societal and political terms is generally indicative of Muslims that are part of one or another reformist tradition (Larsson 2006). This could, on the one hand, be understood as an example of how Islam is brought into the public sphere to participate in defining and setting boundaries between the private and public sphere, but on the other, since Sana brings forward the similarities with Swedish society, not the differences, a border between the two is not created (Casanova 1994:6).

\footnotetext{
${ }^{14}$ In Sweden, handicapped children are supplied with state-paid resource persons to help them in school.
} 


\section{Islamic History in its Swedish Context}

When teaching Islamic history through narrative traditions, all the three schools emphasize ethics, especially regarding how 'good Muslims' should conduct themselves in society - using pedestrian crossings, considering the needs of neighbours, respecting the beliefs of others, and so forth. The teachers consider the narratives to be valuable references when deciding what is right or wrong in their lives.

Narratives are also used to explain the Quran and convey theological messages, and could thus be seen as teachers' attempts to establish the 'right faith' with reference to a number of currently debated issues-both in Sweden and globally-concerning the degree to which Islam should guide all aspects of life, gender equality, and so forth. Their choices also express different ways of relating to authority, i.e. whose interpretation should be chosen; for example, that of established scholars or the teacher's own interpretation. Each teacher's specific selection of narratives as well as the manner in which these are utilized and explained in the classroom brings out differences in interpretive traditions.

The articulated desire to address the 'present situation of the pupils' took a variety of forms among the studied teachers. Certain narratives also had the aim of counterbalancing the negative image of Islam seen to exist in the greater Swedish society, a selection that points to the fact that the teachers consider this image troublesome for the pupils. The selection of narratives that depict important women in Islamic history, for example, can be viewed as an attempt by teachers to provide examples for children to counter the presumption that women hold a low position in Islam.

Several of the choices of content at the schools express the teachers' view that Swedish Muslims, as a cultural and religious minority, must exhibit virtue in relation to the nonMuslim majority. It should be noted, however, that the non-Muslims to whom pupils are encouraged to behave well towards are invariably Christians or Jews, i.e. 'believers'; the possibility of encountering non-believers never really arises in classroom 
discussions. Since a large part of the Swedish population are self-declared 'agnostics' and many are atheists, this shows that in spite of the best intentions to connect IRE with Swedish social reality, that reality itself is perceived through a peculiarly Muslim lens.

\section{Concluding Discussion}

I will now return to the questions posed in the beginning and discuss how we can understand Islamic history as used in IRE as a lived classroom practice in relation to its Swedish context, and whether Islam in Sweden is following the same overall secularizing pattern as the national church, or developing into a de-privatized public religion in Casanova's sense.

In all the studied schools IRE is articulated by the teachers as a subject that guides pupils into Islam by showing them the best possible way to live their lives as Muslims. In most cases, the teachers describe the overriding aim of their instruction in similar terms: to enable pupils to become 'good Muslims' in Swedish society; to become acquainted with Islam's history and religious texts; and to become familiar with Islamic practice. Moreover, all the teachers express similar concerns about the 'negative image' of Islam in Swedish society and also express that learning about Islamic history is essential to their pupils' future as Swedish Muslims. They also consider it to be a risk that the pupils might feel lost in Swedish society if they do not have a fixed ethical point of reference when they have to make decisions in life. For these teachers, this point of reference is Islam. But Swedish IRE classrooms potentially contain teachers and pupils of various ethnic backgrounds belonging to different theological traditions that practice Islam in a variety of ways. Consequently, the same questions that all the teachers agree are important are addressed slightly differently in different classrooms.

The use of Islamic history indicates that discussion on matters such as 'authentic Islam' and what aspects of life Islam should influence are part of the teaching that is offered in Swedish Muslim schools. The teachers themselves express a desire to keep within the limits of Islamic laws (sharia), however, to varying degrees, each can be seen to press for change. On the one hand, existing interpretations and previous opinions of renowned 
Islamic scholars are employed to account for educational choices and the form of Islam that is brought forward in the classrooms; on the other hand, these interpretations and opinions function to restrict those choices, as do the 'foundational' values of Sweden's national curriculum. It should be noted in this connection that adapting the content of IRE is not a matter of inventing new interpretations or Islamic traditions; it is a matter of shifting perspectives on what in the common Islamic tradition is considered to be fundamental, essential and relevant. In this study, these shifts are often based on each teacher's assessment of what ethics and faith are 'required' for Muslim children within the framework of Swedish society. This demonstrates how tradition, local school context, situational perceptions and globally/nationally debated issues merge to affect the content of IRE, and thereby the type of Islam that is promoted in these classes.

It is well known that teachers necessarily interpret the 'foundational' values of the national curriculum differently, depending on personal background. Concerning these Muslim teachers, this might include experiences of socio-cultural isolation and discrimination, and of having your religion misrepresented in the media and certain books. This study shows how teachers attempt to counterbalance and redress these experiences by encouraging the children to develop feelings of connectedness to both Islamic traditions and Swedish society, by referring the content of IRE to both contexts. Other content-related decisions were described as necessary adaptations in response to the goals and requirements of the national curriculum as well as the pupils' situation in Sweden. In this regard, it appeared to be in response to lived classroom circumstances and teacher-pupil interactions - the 'acute' educational context - that adaptations were apparent. These adaptations, which appear as ordinary classroom dialogues, teacher statements and real-time choices, carry the potential of eventually leading to subtle shifts in interpretation regarding such matters as the role of Muslim women, etc.

The endeavour of various groups and individuals to gain space for their particular understanding of Islam is of significance because competing opinions exist about a number of relevant issues: e.g., the degree to which Islam should guide the lives of adherents; the manner in which Muslim minorities should interact with the majority 
society; attitudes towards Western cultural expressions and values; the status and role of women, etc. One way of characterizing the competition between disparate voices within a religious tradition is as an internal struggle for space; but one can conceive of a type of external struggle as well-one in which articulations are primarily intended to sway the opinions and attitudes of the majority society. Since Sweden reformed its educational policies in 1992 to make it possible for a diversity of religious actors to obtain state funding for independent schools, the emerging schools have created a community standing and voice for minority traditions that provides one way of engaging in an external struggle for space, a struggle that tends to promote the development of Islam rather as a de-privatized religion, with Muslim schools being visible institutions within Swedish society, afforded the opportunity of entering into dialogue with majority institutions as equivalents and, by so doing, creating a space for outside recognition of their particular notion of 'authentic Islam'.

This brings forward the role of the secular majority society for the outcome of the question of the de-privatization of Islam in Scandinavia that is the subject of this volume. The tendency to focus on faith and ethics as well as connecting to a discourse of Islam as a private matter could be construed in relation to what questions are considered to belong to religion not only by the secular majority society but also within the Church of Sweden, the former state church. This tendency encapsulates the secular assumption that religion belongs to the private sphere not the public. In one way this view creates a paradox in relation to those who argue that Muslim schools do not belong in a secular society since it gives the same answer as secularism to the question about where there is room for religion, i.e. not in public sphere (school), thereby moving religion away from the public realm. But although there is a discourse concerning Islam as a private matter among Swedish Muslims, thereby following the thesis of 'privatization' of Islam as a step towards secularization, it is generally not accepted by the majority society since Islam as private (functioning as the faith and ethics of individuals) still tends to be visible in the public sphere in ways other than ProtestantLutheran Christianity (food, certain clothing, holidays, schools, etc). In this sense Islam 
tends to be viewed as deprivatized even though it to a certain extent is not articulated in this way.

When the Swedish national public school curriculum states that it does not in theory prioritize one religion before any other, but in reality tends to exclude looks and behaviours related to other worldviews, it pushes people into creating their own institutions. As has been brought forward in the introduction to this volume, despite the general tendency to view religion as a private matter and mainly concerned with faith and morality, many Swedes are Protestant in terms of actions but not in terms of beliefs, which for example could be viewed in the general neglect of holidays other than Protestant Christian ones as well as in attitudes towards clothing. In this way the establishment of Muslim schools in Sweden thereby confirms the notion that there is no room for Islam in the vast majority of schools, which are not religious.

The fact that many Muslim schools have been established in response to bad experiences at municipal schools involving feelings of humiliation and exclusion, with parents having been treated like outsiders, also points in a direction that could be understood as if Islam when held as a private matter is not accepted, since the private/individual choice of food, clothing, celebration of festivities are actions that have been criticized or not accepted by teachers or school personnel and thereby caused these parents and pupils to feel excluded of the sphere of belonging and participation. For these reasons, they have occasionally decided to establish their own school. One way of understanding the establishment of independent Muslim schools in Sweden is, as mentioned above, as an outgrowth of two trends: the need for tolerant, understanding and supportive environments on the one hand, and the demand for recognition, equal opportunity and full participation on the other. It could be understood as a way for Muslims to take power over what is stated in the national curriculum: 'all parents will feel able to send their children to school confident that they will not be prejudiced in favour of a particular view' (Curriculum for the Compulsory School System, the Preschool Class and the Leisure-time Centre 2006:4). Since the existence of Muslim schools has created a good deal of debate in the Swedish society, the reaction could be 
interpreted as a sign that according to the majority society this is not considered the 'right' way for a minority to take action over education.

One could of course argue that the very fact that many more Christian than Muslim schools exist suggests the opposite, but there is an important difference. The establishment of Christian schools seems to have more to do with what parents want to add to their children's schooling than the Muslim ones, where parents rather state that they want to get away from a situation where they feel humiliated and excluded.

Not surprisingly there is no simple answer to the question whether Islam in Sweden is following the same overall secularizing pattern as the national churches, or whether it is developing into a 'de-privatized public religion'. In relation to the study presented in this chapter I claim that to a large extent the understandings of Islam that guide the content of IRE in these Muslim schools are following the Swedish secularization pattern, shown for example by the fact that the teachers repeatedly refer to faith and ethics as what signifies Muslim life in Sweden. Even though there are implicit references to Islam's potential for guiding society as well as politics made in IRE, in the classrooms where I have been, this is done with reference to similarities to Swedish society, not as an alternative societal order which instead would indicate a deprivatization.

\section{References}

Abu Shaqqa, 'Abd al-Halim, 1990: Tahrir al-mar'a fi 'asr ar-risala. Dar al-Qalam li nNashr wa t-Tawzi: Kuwait.

Agar, Michael, 1996: The Professional Stranger, Academic Press: San Diego.

Ajagan-Lester, Louis, 2001: Utbildning i det mångkulturella samhället. Institutionen för pedagogik och didaktik, Göteborg.

Bergesen, Helge Ole, 2003: “Hvorfor frittstående skoler”, in Torgeir Flateby (ed.): Tusenfryd. Didakta, Oslo. 
Berglund, Jenny, 2010: Teaching Islam, Islamic Religious Education at Muslims Schools in Sweden. Waxmann, Münster.

Berglund, Jenny and Göran Larsson (eds.), 2007: Religiösa friskolor i Sverige: Historiska och nutida perspektiv.Studentlitteratur, Lund.

Bunar, Nihad and Kallstenius, Jenny. 2006: "I min gamla skola lärde jag mig fel svenska”: En studie om skolvalfriheten $i$ det polariserade urbana rummet, Integrationsverket, Norrköpin.

Carlbom, Aje, 2003: The Imagined versus the Real Other: Multiculturalism and the Representation of Muslims in Sweden. Sociologiska institutionen, Lund.

Casanova, José, 1994: Public Religions in the Modern World, The University of Chicago Press, Chicago.

Curriculum for the Compulsory School System, the Pre-school Class and the Leisuretime Centre 1994. 2006. Fritzes, Stockholm.

Eickelman, Dale F. and James Piscatori, 2004: Muslim Politics. Princeton University Press, Princeton NJ.

Eliasson, Ragnar, 2006: Skolan och den vetenskapliga teorin om evolutionen. Stockholm: Skolverket.

Glaser, Barney G., 1998: Doing Grounded Theory: Issues and Discussions. Sociology Press, Mill Valley CA.

Hammersley, Martyn and Atkinson, Paul, 1995: Ethnography: Principles in Practice, Routledge, London.

Hartman, Sven, 2007: “The Development of the Swedish Educational System” in Marie Carlsson, Annika Rabo and Fatma Gök (eds.): Education in "Multicultural" Societies: Turkish and Swedish Perspectives, 18: Swedish Research Institute in Istanbul Transactions, pp. 257-265.

Izzi Dien, M.Y. 2008: “Sadd al-Darai”, In P. Bearman, T. Bianquis, C.E. Bosworth, E. van Donzel \& W.P. Heinrichs (eds.): Encyclopedia of Islam. Brill Online: Leiden.

Jackson, Robert, 2003: "Should the State Fund Faith Based Schools? A Review of the Arguments", British Journal of Religious Education, 25 (2), 89-102. 
Jackson, Robert. 2005: Rethinking Religious Education and Plurality, Routledge Falmer, London.

Jensen, Tim, 2004: “Muslimske friskoler i Danmark", Svensk Religionshistorisk Årsskrift 2004, 13.

Johnsson, Helene and Castelli, Mike, 2002: "Beyond Orientalism, How to Understand the Culture of Muslim Schools in England: Some Methodological relflections", International Journal of Education and Religion, III: 33-45.

Larsson, Göran. 2006: Att läsa koranen: En introduktion, Verbum, Stockholm.

Maréchal, Brigitte, 2002: “Teaching Islam at Publicly Financed Schools in Europe”, in Wasif Abdelrahman Shadid and Pieter Sjoerd van Koningsveld (eds.): Intercultural Relations and Religious Authorities: Muslims in the European Union. Peeters, Leuven.

Modood, Tariq and Kastoryano, Riva. 2006: "Secularism and the Accommodation of Muslims in Europe", in Tariq Modood, Anna Triandafyllidou and Ricard Zapata-Barrero (eds.): Multiculturalism, Muslims and Citizenship. Routledge, London.

Raudvere, Catharina, 2002: Stigma, status och strategier: Genusperspektiv $i$ religionsvetenskap. Studentlitteratur, Lund.

Roald, Anne-Sofie, 2001: Women in Islam, the Western Experience. Routledge, London.

Sutcliffe, Steven, 2004: Religion: Empirical Studies. Ashgate, Aldershot \& Burlington.

\section{TV Programmes}

I skolans våld and I skolans våld 2 (In the school's clutches and In the school's clutches 2), broadcast on 8 May 2003 and 12 May 2004 at SVT [Swedish Television], directed by Evin Rubar.

\section{Internet}

Skolverket 2006:

http://www3.skolverket.se/friskola03/1_sok_i_be_p.aspx?skolkategori=GR\&inr 


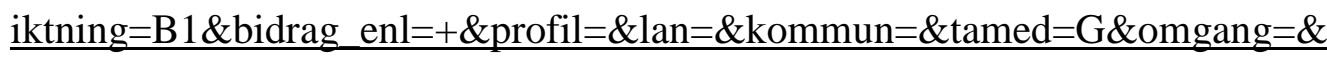

B1=Skicka. Accessed 3 March 2010. 